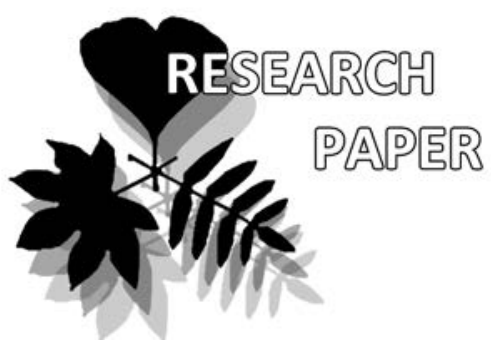

\title{
Wood and bark anatomy of South African Picrodendraceae with systematic and ecological implications
}

\author{
Robin Maruta ${ }^{1}$ \& Alexei A. Oskolski ${ }^{1,2}$
}

Robin Maruta ${ }^{1}$

e-mail: robinmaruta@gmail.com

Alexei A. Oskolski ${ }^{1,2}$

e-mail: aoskolski@uj.ac.za

\author{
${ }^{1}$ Department of Botany and Biotechnology, \\ University of Johannesburg, Johannesburg, \\ South Africa \\ ${ }^{2}$ Komarov Botanical Institute, \\ Saint Petersburg, Russia \\ * corresponding author
}

Manuscript received: 21.09.2021

Review completed: 29.10.2021

Accepted for publication: 05.11.2021

Published online: 08.11.2021

\begin{abstract}
A B S T R A C T
Wood and bark structure of Androstachys johnsonii and Hyaenanche globosa (Picrodendraceae) is described. Two species share simple perforation plates, minute to small intervessel pits, and nonseptate fibres; these traits also reported in other Picrodendraceae. Androstachys is distinctive in having scanty paratracheal axial parenchyma and uniseriate rays with vessel-ray pits restricted to marginal cells. Bordered pits on fibre walls is an ancestral condition for the African Picrodendraceae. High vessel frequency and vessel grouping in Androstachys can be adaptive for semi-arid climate with wet summer. Both genera share the subepidermal phellogen initiation and the presence of thick-walled fibers and sclereids in secondary phloem. In Hyaenanche, the bark is dilated by stretching and divisions of parenchyma cells with formation of pseudocortex. Androstachys shows no ray dilatation, but sclerification of its parenchyma can make substantial contribution in bark expansion. Abundant trichomes on epidermis of young shoots of Androstachys are presumably involved in the water uptake from mists.
\end{abstract}

Keywords: Androstachys, Hyaenanche, Malpighiales, secondary phloem, bordered pits, vessel-ray pits, pseudocortex, sclereids, phloem fibres, trichomes, dilatation

\section{P E 3 Ю M E}

Марута Р., Оскольский А.А. Анатомия Аревесины и коры южноафриканских преАставителей Picrodendraceae в связи с их систематикой и экомогией. Исследовано анатомическое строение Аревесины и коры Androstachys johnsonii и Hyaenanche globosa (Picrodendraceae). Обы вида имеют простые перфорационные пластинки, мелкие межсосудистые поры и несептированными волокна, характерные и Аля многих Аругих Picrodendraceae. Androstachys отличается от Hyaenanche и большинства других преАставителей семейства скудной паратрахеальной аксиальной паренхимой и однорядными Аучами, которые контактируют с сосудами через поры, имеющиеся Аишь на краевых рялах клеток. Последний признак впервые указан А^я Picrodendraceae. По-видимому, высокая частота и сгруппированность просветов сосудов у Androstachys могут быть аАаптивны Аля полуариАного кАимата с влажным Аетом. Что касается строения коры, то оба рода сходны по субэпидермальному заложению феллогена и по наличию толстостенных волокон и склереил во вторичной флоэме. Аилатация коры у Hyaenanche существляется путём растяжения и Аелений паренхимных клеток с образованием псевдокортекса. У Androstachys нет мучевой Аилатации, оАнако склерификация паренхимы вносит существенный вклаА в увеличение периметра коры. По-вилимому, обильное опушение на эпидермисе молоАых побегов Androstachys участвует в улавливании воды из тумана.

Ключевые слова: Androstachys, Hyaenanche, Malpighiales, вторичная флоэма, окаймменные поры, поры межАу сосудами и кучами, псевдокортекс, склереиды, Аубяные волокна, трихомы, Аилатация
Picrodendraceae Small is a pantropical plant family of the order Malpighiales comprising about hundred woody species belonging to 25 genera ranged within the New World, Africa, South Asia and Australasia with the greatest diversity in Australia where ten genera (seven endemic) with 40 species occur (WCSP 2018, Grímsson et al. 2019). This group has long been considered as a subfamily Oldfieldioideae of the family Euphorbiaceae. As the paraphyly of Euphorbiaceae s. lato. has been shown by molecular phylogenetic studies (Chase et al. 1993, 2002, Savolainen et al. 2000, Soltis et al. 1997, 2000, and others), the APG II classification of angiosperms (APG 2003) recongized
Picrodendraceae and four other euphorbioid monophyletic lineages at family rank.

Two major monophyletic groups, i.e. Afro-Indian clade (including the neotropical genera in basal position) and Australasian clade, have been revealed within extant Picrodendraceae (Grímsson et al. 2019). The macrofossil and pollen record of Picrodendraceae along with the current phylogenetic framework strongly suggests that this family originated in the late Cretaceous in the Americas. During the early Paleogene, different lineages of Picrodendraceae dispersed from South America across Antarctica into Australasia, and, independently, across the North Atlantic 
Land Bridge and into Europe. The family migrated from Europe into Africa in the Eocene, and reached India from Africa in the Neogene (Grímsson et al. 2019).

The anatomical structure of wood and especially of the bark of Picrodendraceae is poorly explored. Although brief wood anatomical descriptions and microphotos were published for 16 genera of this family (Kromhout 1975, Araujo \& Filho 1984, Hayden 1994, InsideWood 2004onwards), the available data on variation of quantitative wood traits are very scarce. The bark structure has been studied only in Piranhea longepedunculata Jabl. (Roth 1981, 2005); Pax (1884) reported also the occurrence of sclereids in the bark of Hyaenanche globosa. The aim of current study is the detailed examination of wood and bark structure of Androstachys and Hyaenanche, two South African genera of Picrodendraceae.

Both Androstachys and Hyaenanche are monospecific genera. Androstachys johnsonii Prain, also called Lebombo-ironwood, is an evergreen erect dioecious tree up to $15-20 \mathrm{~m}$ in height distributed from Zimbabwe and Mozambique to Eswatini and to the eastern parts of provincies Limpopo and KwaZulu-Natal in South Africa. This tree occur in deciduous woodland or in pure stands forming Androstachys thickets (Coates Palgrave 2001). Male flowers of this species have numerous spirally arranged stamens on elongate floral axes, and this is an unique condition within angiosperms (Webster 2014, Sokoloff et al. 2018). A. johnsonii is a multiuse species in southern Africa, with numerous advantages to benefit human communities. It is generally valued for its hard and heavy wood that is not prone to termite damage. This wood is utilized for domestic flooring, furniture, musical instruments as well as for fencing, roofing, housing wall pillars, and for many other uses (Dyer et al. 2016, Bakali et al. 2017).

Hyaenanche globosa (Gaertn.) Lamb. \& Vahl, or gifboom ("poison tree" in Afrikaans), is a shrub or small tree up to $5 \mathrm{~m}$ tall growing in open semi-arid fynbos vegetation. The range of this species is confined to the northern Bokkeveld Escarpment Mountain Plateau in the northern Western Cape, South Africa. H. globosa has very toxic fruits which have been reportedly used by Khoisan to make the arrow poison. Also, the local farmers used these fruits for poisoning hyaenas and other livestock predators (Coates Palgrave 2001, Van Jaarsveld 2011). Some toxic substances, such as sesquiterpene lactones, hyaenanchin, and tutin, were isolated from the fruit of this species (Momtaz et al. 2010). The biological role of these toxin is suggested as the deterrence of non-dispersing seed predators, such as Namaqua rock rats (White \& Midgley 2021).

Wood structure of $A$. johnsonii and $H$. globosa has been briefly surveyed by Hayden (1994). The wood anatomical information on the former species there is also in Kromhout's (1975) book and in the InsideWood (2004-onwards) database. Some bark traits of $H$. globosa were reported by Pax (1884), whereas $A$. johnsonii has never been explored by bark anatomists. In the present study, we examine the wood and bark structure of Androstachis and Hyaenanche, in order to elucidate the evolutionary pathways and ecological significance of selected anatomical traits within this plant lineage.

\section{MATERIAL AND METHODS}

The sample of Androstachys jobnsonii [A. Oskolski \# 25818] used for the anatomical investigations was collected by the second author on 12.12.2018 in the miombo woodland in the Brackenridgea (Mutavhatsindi) Nature Reserve in ca. $2 \mathrm{~km}$ from Thengwe village, Limpopo province, South Africa, with permission of its administration. The sample of Hyaenanche globosa (A. Oskolski \# 324-19) was collected by the second author in 26 August 2019 in fynbos near the summit of Bokkeveld Escarpment Mountain in ca. $30 \mathrm{~km}$ from Vanrhynsdorp, Western Cape, South Africa, with permission of the CapeNature. The stem parts at different developmental stages from young twigs to portions of mature branches $(4 \mathrm{~cm}$ in diameter for $A$. johnsonii and 5 $\mathrm{cm}$ for $H$. globosa) were collected. The specimens were fixed in $70 \%$ ethyl alcohol. Herbarium vouchers are deposited in JRAU; the wood and bark samples are deposited at the Department of Botany and Plant Biotechnology, University of Johannesburg, South Africa, and in the Xylarium of the Komarov Botanical Institute, St. Petersburg, Russia (LEw).

Standard procedures for the study of wood structure were employed to prepare sections and macerations for light microscopy (Carlquist 2001). The wood structure was also investigated by scanning electron microscopy (SEM, TESCAN, soft - VegaTS) at the The Central Analytical Facility of the Faculty of Science, University of Johannesburg (Spectrum). Samples for SEM observations were mounted on aluminum stubs with double-sided carbon tape and coated with gold. Descriptive terminology follows Carlquist (2001) and the IAWA List of Microscopic Features for Hardwood Identification (IAWA Committee 1989). The diameters of vessel lumina and fibres were measured in tangential dimension, whereas the diameters of borders of intervessel pits and the pits in fibres were measured in the vertical direction (as the vertical pit size is less variable than the horizontal one, and this is more appropriate for systematic and diagnostic purposes). The quantitative data on wood structure are summarized in Table 1.

For anatomical examination of juvenile stems and of mature bark, the samples were also embedded in glycol methacrylate (GMA) according to a modification of the Feder \& O’Brien (1968) method. Transverse, tangential and radial sections of about $1 \mu \mathrm{m}$ thick were cut by using a Porter Blum MT-1 98 ultramicrotome, then stained with Schiff - toluidine blue method, and mounted in Entellan. Macerations were made using Jeffrey's solution (Johansen 1940). Descriptive terminology followed the recommendations of Angyalossy et al. (2016) for bark description. We also used the term 'pseudocortex' proposed by Whitmore (1962a, 1962b) for a zone of living parenchymatous tissue of mixed origin (both from cortical tissues and from phelloderm and/or secondary phloem parenchyma) located to the outside of dilated secondary phloem. The quantitative data on the lengths of sieve tube members and secondary phloem fibres are also included in Table 1.

Evolution of selected wood anatomical features was clarified by mapping discrete characters on a subsample of the Maximum Clade Credibility consensus timetree of Picrodendraceae of the combined analysis of 3 nuclear, 5 
Table 1. Quantitative anatomical characters of wood and bark in Androstachys jobnsonii and Hyaenanche globosa

\begin{tabular}{lcc}
\hline Characters & $\begin{array}{c}\text { Androstachys johnsonii } \\
\text { [A. Oskolski 258-18] }\end{array}$ & $\begin{array}{c}\text { Hyaenanche globosa } \\
\text { [A. Oskolski 324-19] }\end{array}$ \\
\hline $\begin{array}{l}\text { Diameter of vessels } \\
\text { (mean } \pm \text { standard error, min-max, } \mu \mathrm{m})\end{array}$ & $28.3 \pm 1.23$ & $31.4 \pm 1.01$ \\
Vessel frequency per mm ${ }^{2}$ (mean, min-max) & $11-43$ & $17-51$ \\
Mean/max number of vessel lumina per group & 237.5 & 55.0 \\
Percentage of solitary vessels & $201-280$ & $47-66$ \\
Vertical size of intervessel pits & $1.54 / 6$ & $1.14 / 4$ \\
(mean, min-max, $\mu \mathrm{m}$ ) & 43 & 79 \\
Vessel elements length & 4.3 & 3.2 \\
(mean \pm standard error, min-max, $\mu \mathrm{m})$ & $3.2-6.7$ & $2.1-4.0$ \\
Length of wood fibres & $581.9 \pm 22.17$ & $480.3 \pm 20.73$ \\
(mean \pm standard error, min-max, $\mu \mathrm{m})$ & $264-1076$ & $207-860$ \\
F/V ratio & $815.1 \pm 24.01$ & $745.1 \pm 23.72$ \\
Height of rays & $264-1076$ & $407-1225$ \\
(mean, min-max, $\mu$ m) & 1.40 & 1.55 \\
Number of uniseriate rays per mm & 127.4 & 299.7 \\
(mean, min-max) & $52-231$ & $71-1001$ \\
Number of multiseriate rays per mm & 7.3 & 3.9 \\
(mean, min-max) & $3.8-13.3$ & $1.9-8.6$ \\
Total number of rays per mm & 0 & 11.7 \\
(mean, min-max) & 7.3 & $7.6-15.2$ \\
Length of sieve tube members & 15.6 \\
(mean \pm standard error, min-max, $\mu \mathrm{m})$ & $3.8-13.3$ & $11.4-19.0$ \\
Length of secondary phloem fibres & $326.2 \pm 45.32$ & $167-295$ \\
(mean \pm standard error, min-max, $\mu \mathrm{m}$ ) & $198-402$ & $868.6 \pm 28.31$ \\
\hline
\end{tabular}

mitochondrial and 4 plastid regions (Grimsson et al. 2019). Character optimization along the branches of the tree was illustrated using the parsimony reconstruction method of the Character History Tracing option in the computer package Mesquite 2.75 (Maddison \& Maddison 2011).

To clarify the climatic factors experienced by $A$. jobnsonii and $H$. globosa for interpretation of some differences in their wood and bark structure, we assessed the average values of 19 bioclimatic parameters for the distribution ranges of each species. The values of bioclimatic variables were revealed on the coordinates of the species occurrences that were retrieved from the Global Biodiversity Information Facility (GBIF) web portal (http://www.gbif.org/). The data set consisted of 40 occurrences for $A$. johnsonii (GBIF Occurrence Download https://doi.org/10.15468/dl.dh8n2b, 01 September 2021) and 16 occurrences for H. globosa (GBIF Occurrence Download https://doi.org/10.15468/ dl.xk6bw4, 01 September 2021) was used to extract 19 bioclimatic variables representing the variation of temperature and precipitation from the WorldClim climate layers at a resolution of $2.5 \mathrm{~min}$ (Hijmans et al. 2005) for each occurrence using the Raster package (Hijmans \& Etten 2012) in $\mathrm{R}$. The average values of the bioclimatic parameters for each species showed in Table 2.

\section{RE S U LT S}

\section{Anatomy of Androstachys johnsonii Examined sample: A. Oskolski 258-18}

\section{Wood structure}

Growth ring boundaries are distinctly marked by $3-5$ rows of radially flattened fibres, and also by different vessel frequency between latewood and earlywood. Vessels are roun- ded, rarely angular in outline, narrow (tangential diameter $11-42 \mu \mathrm{m}$, Table 1), solitary and in radial to diagonal multiplies of 2-6, very numerous (202-280 vessels per $\mathrm{mm}^{2}$ ). Vessel walls of $2.8-7.0 \mu \mathrm{m}$ thick (Fig. 1A). Vessel elements are $582 \mu \mathrm{m}(264-1076 \mu \mathrm{m})$ long. Perforation plates are simple (Fig. 1B). Intervessel pits are alternate, minute to small, 3.2-6.8 $\mu \mathrm{m}$ in vertical size (Fig. 1C). Vessels-ray and vessel-axial parenchyma pits are similar to intervessel pits in size and shape, mostly with distinct borders, commonly restricted to marginal rows of ray cells (1D, F). Helical thickenings were not found. Vascular tracheids were not found. Tyloses not found.

Ground tissue fibres are very thick-walled, occasionally thin- to thick-walled (fibre walls 3.3-7.4 $\mu \mathrm{m}$ thick), relatively short (430-1142 $\mu \mathrm{m}$ in length, average $815 \mu \mathrm{m})$. Distinctly bordered pits of 3.1-4.7 $\mu \mathrm{m}$ in vertical diameter with slitlike apertures are common on radial walls, whereas simple to minutely bordered pits found on radial and tangential walls. Septate fibres not found.

Axial parenchyma is scanty paratarcheal, mostly unilateral, in solitary strands near the outer sides of vessels and vessel groups (Fig. 1A), in strands of 3-4 cells. Prismatic crystals occur in chambered cells of axial parenchyma.

Rays 7.3 per $\mathrm{mm}$ (4-13 per $\mathrm{mm}$ ), exclusively uniseriate. Ray height commonly $52-231 \mu \mathrm{m}$. Rays composed of square cells and procumbent upright cells mixed throughout the rays. Radial canals absent. Crystals in ray cells not found (Figs 1D-F).

\section{Bark structure}

Epidermis on young parts of stems is composed of a single layer of isodiametric rectangular to rounded cells of $18-32 \mu \mathrm{m}$ in tangential size with thin inner walls and very thick $(6-10 \mu \mathrm{m})$ outer walls covered by thin cuticle (Fig. 2A). Trichomes are abundant, non-glandular, two-cellular with small basal cell and very long (ca. $1 \mathrm{~mm}$ in length) terminal cell. 

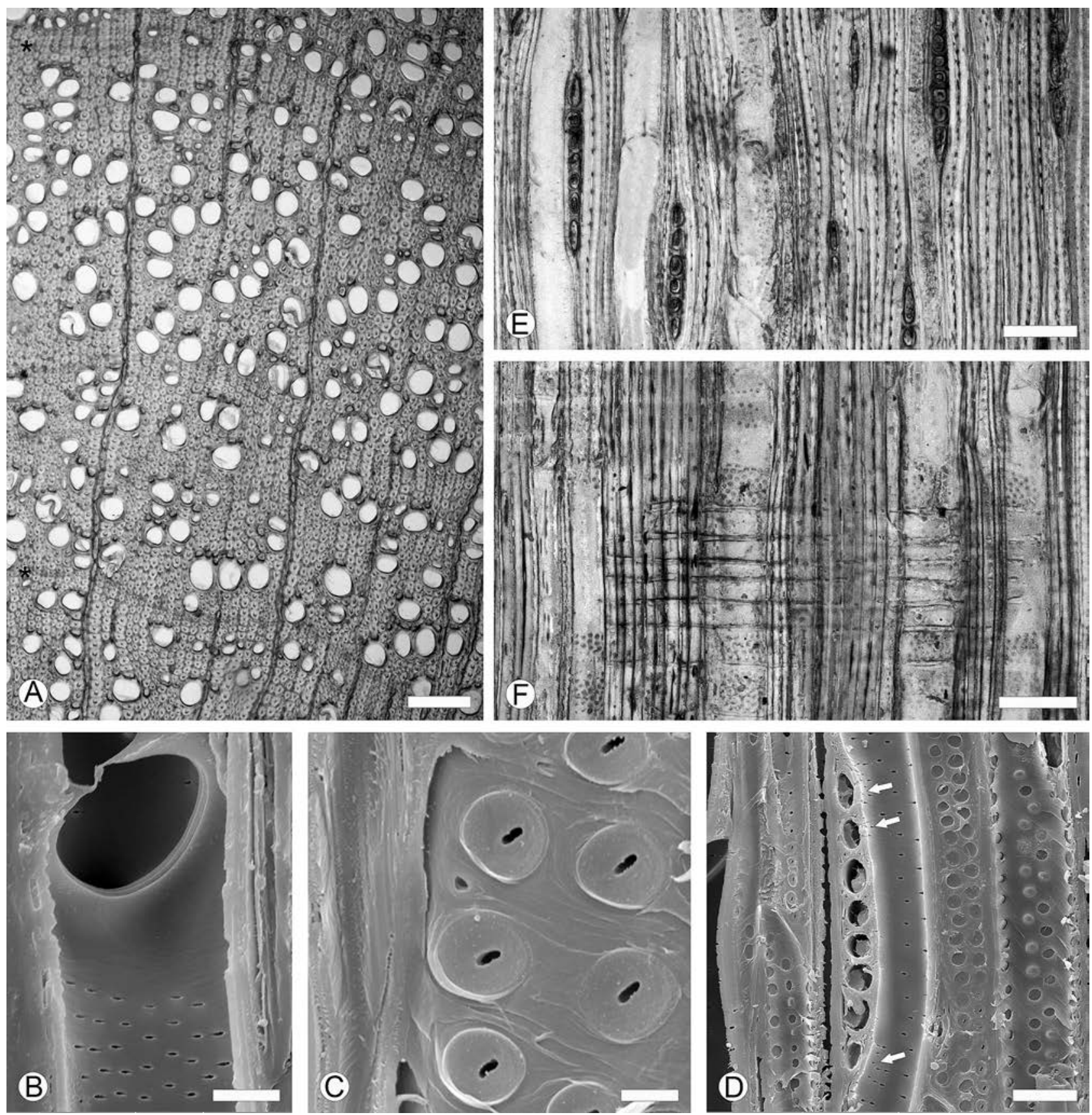

Figure 1 Wood structure of Androstachys johnsonii Prain [A.Oskolski 258-18]: A - distinct growth rings boundaries (asterisks), axial parenchyma mostly scanty unilateral paratracheal and in 1-3-seriate tangential line, light microscopy (LM), transverse section (TS); B - simple perforation plate scanning electron microscopy (SEM), radial longitudinal section (RLS); C - alternate intervessel pits (SEM), tangential longitudinal section (TLS); D - uniseriate ray with vessel-ray pits restricted to marginal ray cells (white arrows) (SEM, TLS); E - exclusively uniseriate rays (LM, TLS); F - procumbent and square ray cells, vessel-ray pits restricted to marginal rows (LM, RLS). Scale bars $=100 \mu \mathrm{m}(\mathrm{A}), 50 \mu \mathrm{m}(\mathrm{E}$, F), $20 \mu \mathrm{m}(\mathrm{D}), 10 \mu \mathrm{m}(\mathrm{B}), 5 \mu \mathrm{m}(\mathrm{C})$

Cortex is narrow, with about 9-10 layers of isodiametric very thin-walled parenchyma cells of $10-22 \mu \mathrm{m}$ in tangential diameter. Prismatic crystals found in some of the cortical parenchyma cells. Pericyclic fibers are thin-walled, in clusters of 2-10, arranged into interrupted band (Fig. 2A).

Mature bark gray to dark brownish, non-peeling, with shallow long parallel fissures, without scaling. The initiation of first-formed periderm is subepidermal. The phellem is composed of 8-12 layers of more or less radially flattened cells with thin cell walls. The phelloderm comprises of 4-7 layers of radially flattened thin- walled cells. Prismatic cells are found in the phellem. Subsequent periderms not found (Figs 2B, C).
Dilated cortex (Fig. 2B) is narrow (10-12 cells wide, i.e. 200-250 $\mu \mathrm{m}$ in width) and well-delimited from outer regions of secondary phloem by the continuous band of peryciclic fibres and sclereids; therefore, the term "pseudocortex" is not appropriate for this zone. Dilation of the cortical tissue is effected mostly by tangential stretching of cells and by anticlinal divisions of the cortical parenchyma cell, thus forming strands of $2-10$ cells. Small $(21-35 \mu \mathrm{m}$ in tangential size) isodiametric sclereids rarely occur in dilated cortex. Crystals not found.

Secondary phloem (Figs 2B, D; 3A, B) consists of 8-15-seriate conductive elements and axial parenchyma alternating with 3-5-seriate tangentially elongated clusters 


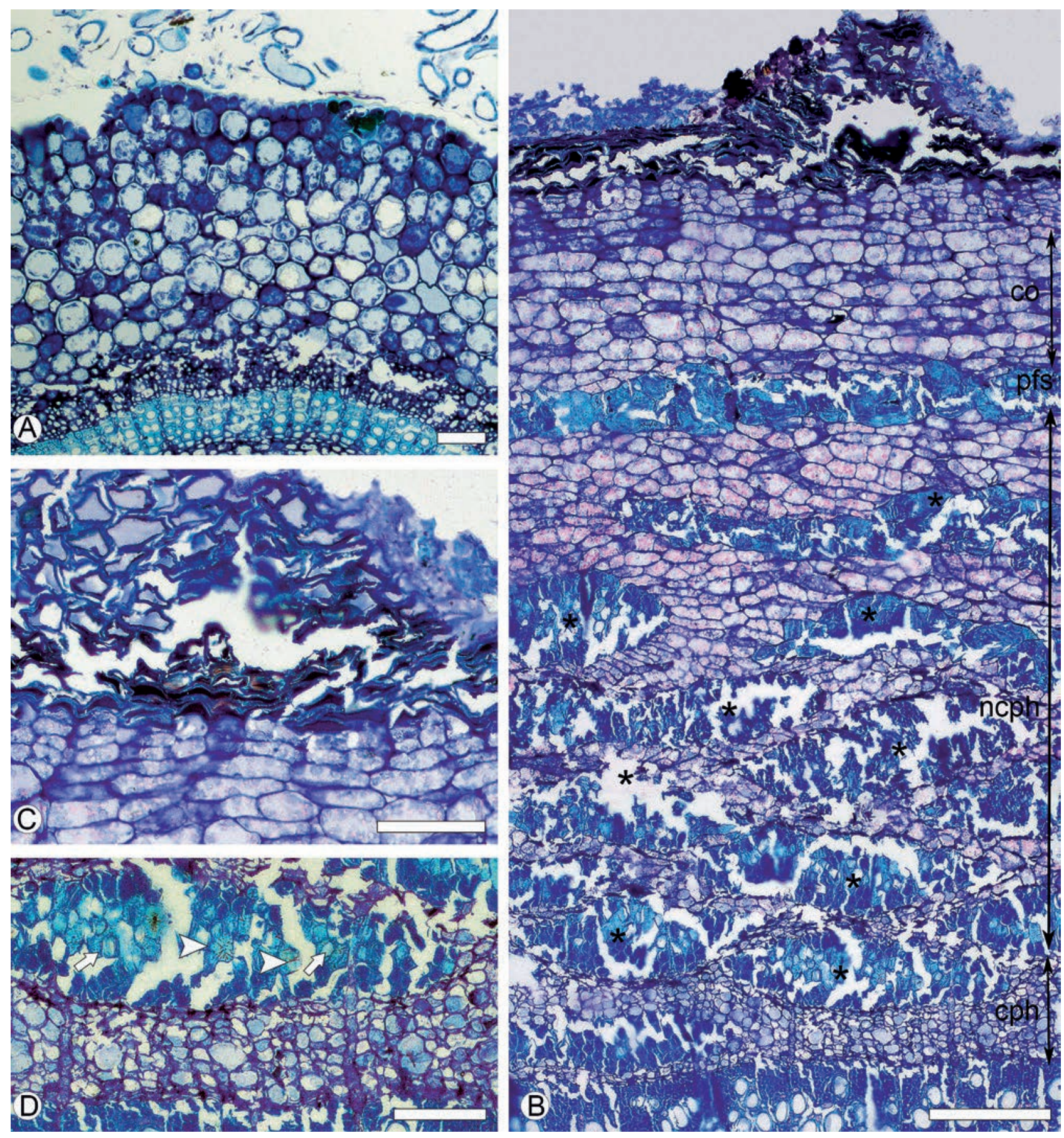

Figure 2 Bark structure of Androstachys johnsonii Prain [A.Oskolski 258-18], transverse sections (LM): A - juvenile stem: epidermis with abundat trichomes, cortex, ring of pericyclic fibres and phloem, secondary xylem; B - mature bark: conducting (cph) and non-conducting (ncph) secondary phloem, clusters of secondary phloem fibres and sclereids (asterisks), band of pericyclic fibres and sclereids (pfs); dilated cortex (co), periderm; C - periderm: phelloderm, thin-walled phellem cells; D - conducting secondary phloem: band of sieve tubes and axial parenchyma, cluster of sclereids (arrowheads), sclerified axial parenchyma strands with prismatic crystals (arrows), and secondary phloem fibres. Scale bars $=200 \mu \mathrm{m}(\mathrm{B}), 50 \mu \mathrm{m}(\mathrm{A}, \mathrm{C}, \mathrm{D})$

of secondary phloem fibers associated with sclereids and partially sclerified axial parenchyma strands with prismatic crystals in chambered cells. Sieve tubes are $20-33 \mu \mathrm{m}$ wide, solitary and in radial groups of $2-4$. The sieve tube members are $326 \mu \mathrm{m}(198-402 \mu \mathrm{m})$ in length. Sieve plates are simple and compound with 2-4 sieve areas, located on vertical or slightly oblique cross walls. Axial parenchyma in strands of 2-4 cells, occasionally with chambered cells containing small prismatic crystals (Figs 2D, 3A). Secondary phloem fibers are very thick-walled, $889 \mu \mathrm{m}(328-1223 \mu \mathrm{m})$ in length. Sclereids rectangle-shaped, isodiametric to somewhat verti- cally elongated of $18-63 \mu \mathrm{m}$ in tangential size, very thickwalled, occasionally with prominent layers in cell walls. Transition from non-collapsed to collapsed secondary phloem is gradual. Dilation of secondary phloem effected mostly by tangential stretching and anticlinal divisions of axial parenchyma forming tangential strands of $2-9$ cells, as well as by sclerification of additional parenchymatous cells making their walls much thicker. In non-conducting secondary phloem, the clusters of sclerenchyma tend to coalesce into continuous tangential bands. 

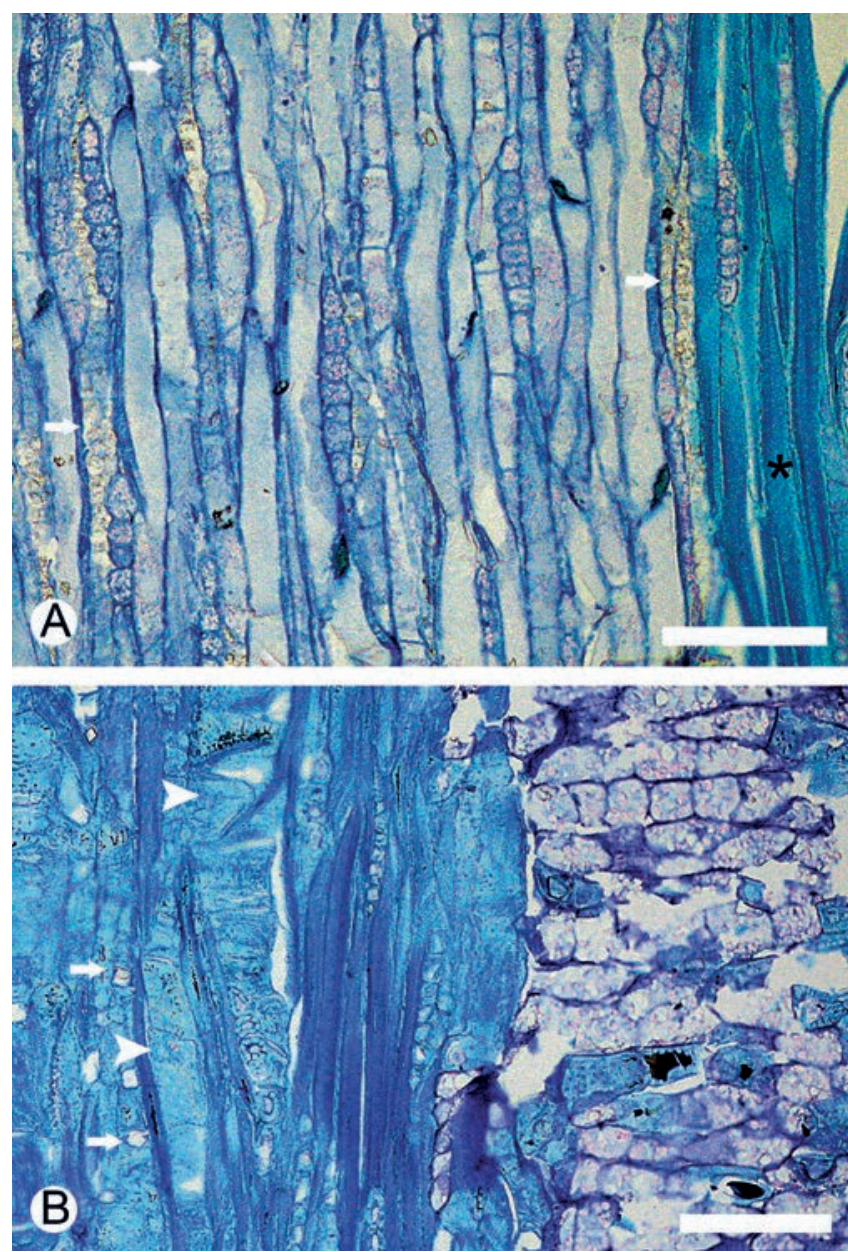

Figure 3 Bark structure of Androstachys johnsonii Prain [A. Oskolski 258-18], tangential longitudinal sections (LM): A - conducting secondary phloem: sieve tube members, crystaliferous (arrows) and non-crystaliferous axial parenchyma strands, uniseriate rays, secondary phloem fibres (asterisk); B - non-conducting secondary phloem: sclereids (arrowheads), secondary phloem fibres, sclerified axia parenchyma strands with prismatic crystals (arrows), dilated axial parenchyma. Scale bars $=100 \mu \mathrm{m}$

Secondary phloem rays are uniseriate, composed of mostly square cells, occasionally also with and procumbent cells in its central portions (Fig. 3A). Dilated rays associated with parenchyma cells are enlarged by tangential expansion, but without anticlinal divisions; sometimes with sclerified cell walls (Fig. 3B). No crystals are found in ray cells.

\section{Anatomy of Hyaenanche globosa Examined sample: A. Oskolski 258-18}

\section{Wood structure}

Growth ring boundaries are indistinct, marked by difference in abundance of vessels and axial parenchyma between latewood and earlywood (Fig. 4A). Vessels are rounded, rarely angular in outline, narrow (tangential diameter $17-51 \mu \mathrm{m})$, predominantly solitary, occasionally also radial multiplies of up to 4 vessels, moderately numerous (47-66 vessels per $\mathrm{mm}^{2}$ ). Vessel walls of 2.2-5.6 $\mu \mathrm{m}$ thick. Vessel elements are $480 \mu \mathrm{m}(207-860 \mu \mathrm{m})$ long (Table 1). Perforation plates are simple (Fig. 4B). Intervessel pits are alternate, minute, $2.1-4.0 \mu \mathrm{m}$ in vertical size (Fig. 4C). Vessels-ray and vessel-axial parenchyma pits are similar to intervessel pits in size and shape, with distinct borders, sometimes unilateral compound, not restricted to marginal ray cells (Figs 4B, F). Helical thickenings were not found. Vascular tracheids were not found. Tyloses were not found.

Ground tissue fibres are very thick-walled, occasionally thin- to thick-walled (fibre walls 3.2-9.8 $\mu \mathrm{m}$ thick), relatively short (407-1125 $\mu \mathrm{m}$ in length, average $745 \mu \mathrm{m})$. Distinctly bordered pits of $3.2-5.0 \mu \mathrm{m}$ in vertical diameter with slitlike apertures are common on radial walls, whereas simple to minutely bordered pits found on tangential walls, and occasionally occurring also on radial walls of fibres (Figs 4D, E). Septate fibres not found.

Axial parenchyma is diffuse-in-aggregates, in strands of 4-7 cells. Prismatic crystals occur in chambered and non-chambered cells of axial parenchyma.

Rays 15.6 per mm (11-19 per mm), uni- and 2-3-seriate. Ray height commonly 175-1068 $\mu \mathrm{m}$. Both uniseriate and multiseriate rays composed mostly of square cells and procumbent cells (occasionally also upright cells) mixed throughout the rays (Figs 4E, F). Radial canals absent. Crystals in ray cells not found.

\section{Bark structure}

Juvenile stems circular in outline, with eight-point star shaped conductive cylinder and square pith (Fig. 5A). Epidermis on young parts of stems is composed of a layer of column-like to isodiametric rectangular cells of $10-23 \mu \mathrm{m}$ in tangential size with thin walls and very thick $(5-9 \mu \mathrm{m})$ outer walls covered by thin cuticle. Trichomes not found.

Cortex is 20-25 cells in width, composed of collenchyma and parenchyma. Cortical collenchyma is angular-lamellar in 2-3 layers of cells which are $20-40 \mu \mathrm{m}$ in tangential diameter, containing no crystals. Cortical parenchyma is of 18-23 layers of isodiametric to thin-walled cells of $30-70 \mu \mathrm{m}$ in tangential diameter, occasionally containing druses. Pericyclic fibers are thick-walled, solitary and in clusters of 2-15 (Fig. 5B).

Mature bark (Fig. 5C) gray, non-peeling, brittle, without fissures and scales. The initiation of first -formed periderm is in subepidermal layer. The phellem is composed of 8-12 layers of more or less radially flattened cells with thin cell walls $(2.5-3.0 \mu \mathrm{m}$ thick). The phelloderm comprises of 7-10 layers of radially flattened thin-walled cells. No crystalliferous cells found in periderm. Subsequent periderms not found (Figs 5C, D).

Pseudocortex found between periderm and dilated secondary phloem as a prominent parenchymatous zone of $1.2-1.4 \mathrm{~mm}$ in width. This bulk of parenchyma is apparently derived from phelloderm, dilated cortical parenchyma, and outer regions of dilated secondary phloem. Dilation of pseudocortex is affected mostly by tangential stretching and by anticlinal divisions of parenchyma cells, thus forming strands of two to ten cells. Large $(90-170 \mu \mathrm{m}$ in tangential size) solitary isodiametric sclereids with very thick walls occur in pseudocortex. Crystals not found (Fig. 5C).

Secondary phloem consists of conductive elements, axial parenchyma and small clusters of 3-8 fibres and isodiametric sclereids associated with the strands of chambered axial parenchyma cells containing prismatic crystals (Figs 5C, E). These clusters of sclerenchyma are scattered 

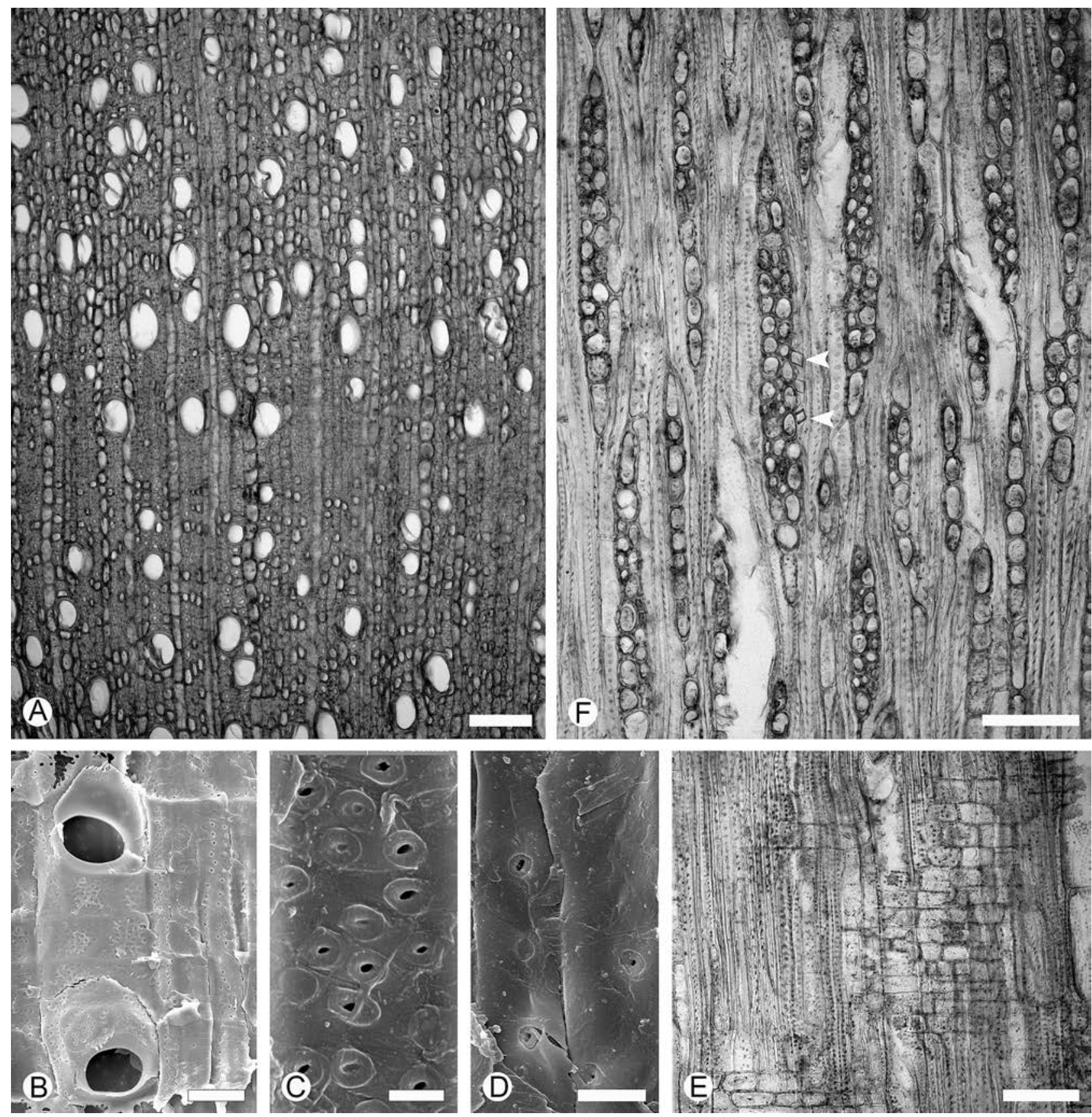

Figure 4 Wood structure of Hyaenanche globosa (Gaertn.) Lamb. \& Vahl: [A.Oskolski 324-19]: A - indistinct growth rings boundaries, axial parenchyma diffuse-in-aggregates (LM, TS); B - vessel element with simple perforation plates, vessel-ray pits with distinct borders (SEM; RLS); C - alternate intervessel pits (SEM, TLS); D - bordered pits on fibre wall (SEM, RLS); E - square and procumbent ray cells, vessel-ray pits not restricted to marginal rows of ray cells (LM, RLS); F - uni- and 2-3-seriate rays, prismatic crystals (arrowheads) in axial parenchyma cells (LM, TLS). Scale bars $=100 \mu \mathrm{m}(\mathrm{A}, \mathrm{E}, \mathrm{F}), 50 \mu \mathrm{m}(\mathrm{B}), 10 \mu \mathrm{m}(\mathrm{D}), 5 \mu \mathrm{m}(\mathrm{C})$

within the zones of conductive elements and axial parenchyma without prominent pattern. Sieve tubes are 20-30 $\mu \mathrm{m}$ wide, in radial groups of $2-7$. The sieve tube members are $217 \mu \mathrm{m}(167-295 \mu \mathrm{m})$ in length. Sieve plates are compound with 2-6 sieve areas, located on vertical or slightly oblique cross walls. Axial parenchyma in strands of $2-4$ cells, occasionally with chambered cells containing small prismatic crystals. Secondary phloem fibers are very thick-walled, 868 $\mu \mathrm{m}(359-1353 \mu \mathrm{m})$ in length. Sclereids rectangle-shaped, isodiametric to somewhat vertically elongated of $15-45 \mu \mathrm{m}$ in tangential size, very thick-walled, ococcasionally with pro- minent layers in cell walls. Transition from non-collapsed to collapsed secondary phloem is gradual. In collapsed secondary phloem, the axial parenchyma cells are tangentially stretched, and the sclerenchyma clusters are more large (up to 20 cells) and numerous. Dilation of secondary phloem effected mostly by tangential stretching and anticlinal divisions of ray cells (Figs 5 C, E, G).

Secondary phloem rays are uniseriate and 2-3 seriate (Fig. $5 \mathrm{~F}$ ). Uniseriate rays are composed of mostly square cells while 2- and 3- seriate rays have procumbent cells in its central portions. Dilated rays are extensively enlarged, most- 

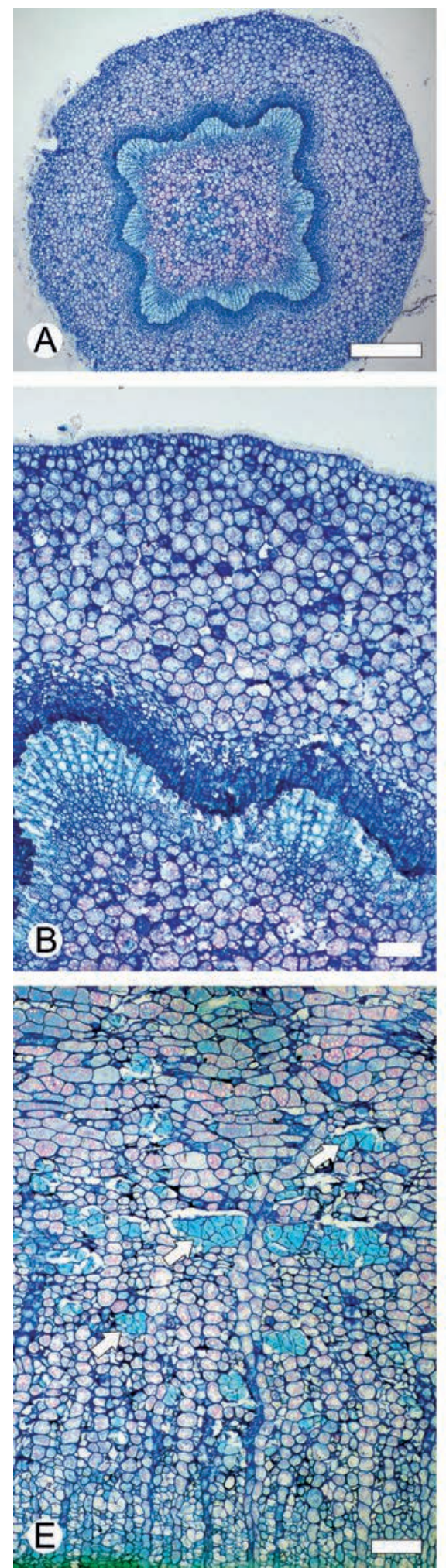
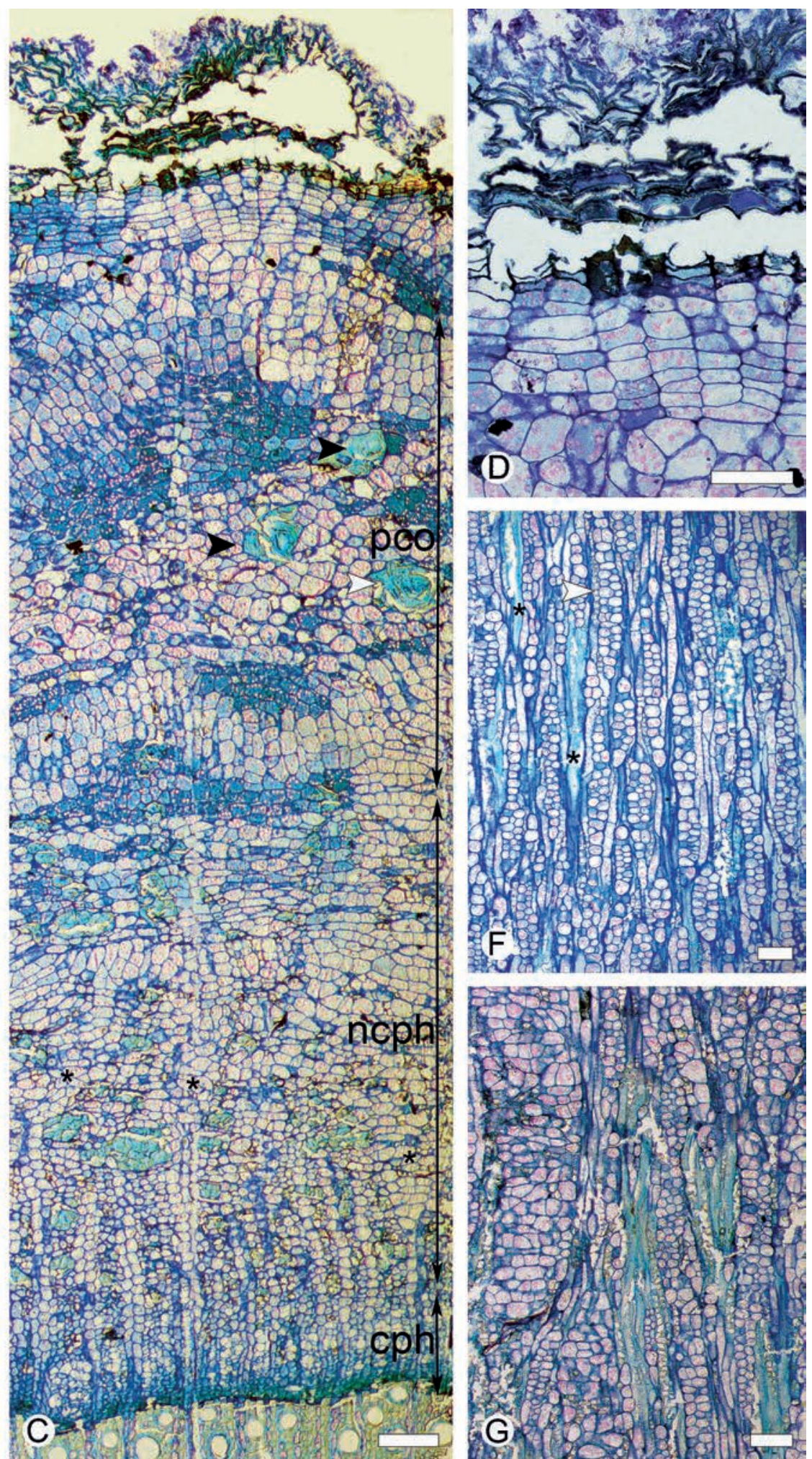

Figure 5 Bark structure of Hyaenanche globosa (Gaertn.) Lamb. \& Vahl [A. Oskolski 324-19], (LM): A - juvenile stem: eight-pointed star shape of conductive cylinder, square pith (TS): B - juvenile stem: epidermis without trichomes, cortex with collenchyma and parenchyma, band of pericyclic fibres and phloem, secondary xylem (TS); C - mature bark: conducting (cph) and non-conducting (ncph) secondary phloem, dilated rays (asterisks), clusters of secondary phloem fibres and sclereids, pseudcortex (pco) with sclereids (arrowheads), periderm (TS); D - periderm: phelloderm, thin-walled phellem cells (TS); E - conducting secondary phloem: sieve tubes and axial parenchyma, clusters of secondary phloem fibres and sclereids (arrows) (TS); F - conducting secondary phloem: sieve tube members, crystaliferous (arrowhead) and non-crystaliferous axial parenchyma strands, uni- and 2-3-seriate rays, secondary phloem fibres (asterisks) (TLS); G - non-conducting secondary phloem: secondary phloem fibres, sclerified axial parenchyma strands with prismatic crystals, dilated rays and axial parenchyma (TLS). Scale bars $=500 \mu \mathrm{m}(\mathrm{A}), 200 \mu \mathrm{m}(\mathrm{C}), 100 \mu \mathrm{m}(\mathrm{B}, \mathrm{D}, \mathrm{E}, \mathrm{F}, \mathrm{G})$ 
ly by tangential expansion and also by anticlinal division of ray cells resulting in rays of up to 12 cells wide. Many of the ray cells contain starch grains. Prismatic crystals occur in the cells of dilated rays (Fig. 5G).

\section{Evolution of some wood traits within Picrodendraceae}

Both our observations on Androstachys and Hyaenanche, and the published wood anatomical data on other Picrodendraceae genera (Hayden, 1994; InsideWood, 2004-onwards) have been used to reconstruct the patterns of evolution for the presence of bordered pits on the fibre walls, the prominence of borders at the vessel-ray pits, the occurrence of multiseriate rays, and the types of axial parenchyma (Figs 6A-D). The mapping of this trait on a subset of the Maximum Clade Credibility consensus timetree of Picrodendraceae of the combined analysis of 3 nuclear, 5 mitochondrial and 4 plastid regions (Grimsson et al. 2019) shows that the lack of bordered pits on fibre walls, the vessel-ray pits with distinct borders, the presence of multiseriate rays, and exclusively apotracheal (diffuse and/ or diffuse-in-aggregates) axial parenchyma are ancestral conditions for this group. The gains of bordered pits occurred in Austrobuxus and, independently, in Hyaenanche and Androstachys, i.e. in the basal lineages of the African clade, with the secondary loss in Oldfieldia and Aristogeitonia (Fig. 6A). Two shifts from distinctly bordered vessel-ray pits to indistinctly bordered or simple ones found in Austrobuxus and Piranhea (Fig. 6B). The multiseriate rays were lost in Androstachys and, independently, in one species of Piranhea (Fig. 6C). The gains of banded axial parenchyma shown in Dissiliaria, Aristogeitonia and Piranbea; the shift from apotracheal axial parenchyma to scanty paratracheal one found only in Androstachys (Fig. 6D).

\section{DISCUSSION}

Androstachys johnsonii and Hyaenanche globosa share a suite of wood traits (exclusively simple perforation plates, minute to small intervessel pits, nonseptate thick-walled imperforate elements, the occurrence of prismatic crystals in axial parenchyma cells) found in most genera of Picrodendraceae explored to date (Hayden 1994, InsideWood 2004-onwards). H. globosa also shows such typical features of this family as apotracheal (mostly diffuse-in-aggregates) axial parenchyma
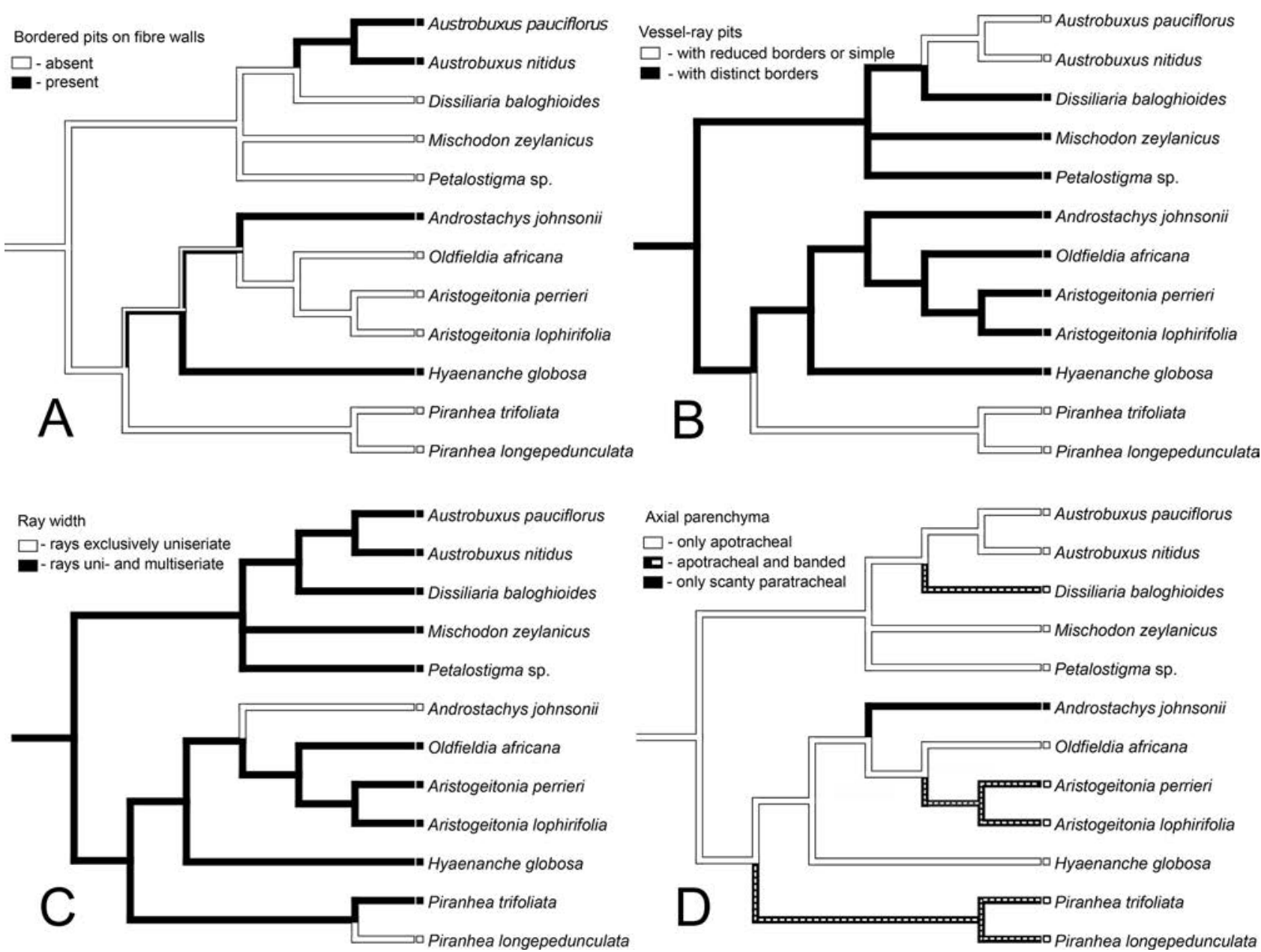

Figure 6 Distribution of the wood character states within the Picrodendraceae mapped onto a subsample of the Maximum Clade Credibility consensus timetree of the combined analysis of 3 nuclear, 5 mitochondrial and 4 plastid regions (Grimsson et al. 2019). A - the presence of distinctly bordered pits on fibre walls (white - absent, black - present); B - the prominence of borders at the vessel-ray pits (white - pits with reduced borders or simple, black - pits with distinct borders); $\mathrm{C}$ - the occurrence of multiseriate rays (white - rays exclusively uniseriate, black - uni- and multiseriate rays); D - the type of axial parenchyma (white - only apotracheal, hatch - apotracheal and banded, black - only scanty paratracheal) 
and numerous mostly multiseriate rays (11-19 rays per $\mathrm{mm})$. Unlike that, $A$. johnsonii has scanty paratracheal axial parenchyma and relatively sparse (4-13 per $\mathrm{mm}$ ) exclusively uniseriate rays. Although these traits are uncommon within Picrodendraceae (Figs 6C-D), Androstachys shares those with two species of a Malagassy genus Stachyandra (InsideWood 2004-onwards). Such a similarity in wood structure confirms close relationships between these two genera sharing also some unique morphological features of their male flowers (Radcliffe-Smith 1990, Webster 2014, Sokoloff et al. 2018). The position of Stachyandra has not yet been examined, however, by molecular phylogenetic analysis.

Androstachys is also distinctive from Hyaenanche in having vessel-ray pits restricted to marginal rows. This feature manifests the differentiation between the contact ray cells and the isolation ones (Braun 1970). The loss of vessel-associated parenchyma cells in the rays of Androstachys is thought to be recouped by the shift from apotracheal axial parenchyma to scanty paratracheal one (Fig. 6D) in this genus (Braun 1984, Morris et al., 2018). Although the vessel-ray pits restricted to marginal rows occur in Phyllanthaceae, Peraceae, Euphorbiaceae, and the majority of other woody families belonging to the order Malpighiales (InsideWood 2004-onwards), this trait has never been reported in Picrodendraceae.

The presence of bordered pits on fibre walls in Androstachys and Hyaenanche is seemingly an ancestral condition for the African clade of Picrodendraceae with its secondarily loss in Oldfieldia and Aristogeitonia (Fig. 6A). This trait has also been reported for the Malagasy genera Stachyandra and Voatamalo (InsideWood 2004-onwards), that also presumably belong to this clade. Following Sano's et al. (2011) data, the bordered pits on fibre walls in both studied species could be able to conduct water due to their large size $(>4 \mu \mathrm{m}$ in diameter). These pits are confined, however, only to radial walls of mostly thick-walled fibers with narrow lumina. These fibers are hardly involved, therefore, in the water conductance in Androstachys and Hyaenanche.
Hayden (1994) suggested great significance of the shape of vessel-ray pits for systematics of Picrodendraceae. This author considered the occurrence of "irregular" (i.e. scalariform or palisade) vessel-ray pits as an ancestral condition reporting the presence of such pits in all Australasian genera of this family as well as in Paradrypetes and Podocalyx, two Neotropical genera. The published reliable information on the variation of shape of vessel-ray pits within Picrodendraceae (Araujo \& Filho 1984, Hayden 1994, InsideWood 2004-onwards) is not sufficient, however, to test this hypothesis. Instead, the mapping of available data on the prominence of borders at the vessel-ray pits (Fig. 6B) suggests that this trait is also of certain value for systematics of some genera, e.g. Austrobuxus and Piranhea.

Androstachys jobnsonii shows much higher vessel frequency (average 273.5 per $\mathrm{mm}^{2}$ ) and grouping (43.3\% of solitary vessels) than $H$. globosa $\left(37.0\right.$ per $\mathrm{mm}^{2}$ and $85.2 \%$, respectively) coupled with nearly equal figures of vessel diameter in both species (average $28.3 \mu \mathrm{m}$ in A. johnsonii, and $31.4 \mu \mathrm{m}$ in $H$. globosa). These differences in vessel traits are thought to be associated with contrating climatic conditions influencing those species. While $H$. globosa is confined to the Mediterranean-type climate with hot dry summer and rainy mild winter (Csa type sensu Köppen \& Geiger's classification; Peel et al. 2007), A. johnsonii is distributed in the regions of hot semi-arid climate with wet summer and dry winter (Bsh type). Although the annual precipitation within the distribution area of the latter species (average $644 \mathrm{~mm}$ ) is more than twice as high as within that of the former one (average $266 \mathrm{~mm}$, Table 2), this rainfall is timed to hot season with high evaporation. Presumably, A. johnsonii has much higher transpiration rate during wet season than $H$. globosa, and more numerous vessels are required for sufficient supply of water to its leaves. If that is the case, the higher vessel grouping in $A$. johnsonii can be a way of increasing safety of water conductance by providing subsidiary conduits whereby water can be carried in case of air embolisms of some vessels in a group (Carlquist 1984,

Table 2. Average values of bioclimatic variables for distribution ranges of Androstachys jobnsonii and Hyaenanche globosa (temperature in ${ }^{\circ} \mathrm{C}$, precipitation in $\mathrm{mm}$ )

\begin{tabular}{|c|c|c|c|}
\hline Abbreviations & Bioclimatic variables & Androstachys jobnsonii & Hyaenanche globosa \\
\hline BIO1 & Annual mean temperature & 22.3 & 17.3 \\
\hline $\mathrm{BIO} 2$ & Mean diurnal range & 12.9 & 15.2 \\
\hline $\mathrm{BIO} 3$ & Isotermality $(\mathrm{BIO} 2 / \mathrm{BIO} 7)(\times 100)$ & 59.5 & 58.7 \\
\hline $\mathrm{BIO} 4$ & Temperature Seasonality (standard deviation $\times 100$ ) & 2941 & 3914 \\
\hline $\mathrm{BIO} 5$ & Max Temperature of Warmest Month & 31.6 & 31.0 \\
\hline BIO6 & Min Temperature of Coldest Month & 10.0 & 5.1 \\
\hline $\mathrm{BIO} 7$ & Temperature Annual Range (BIO5-BIO6) & 21.6 & 25.9 \\
\hline $\mathrm{BIO} 8$ & Mean Temperature of Wettest Quarter & 25.4 & 12.9 \\
\hline BIO9 & Mean Temperature of Driest Quarter & 18.1 & 22.1 \\
\hline $\mathrm{BIO} 10$ & Mean Temperature of Warmest Quarter & 25.4 & 22.2 \\
\hline BIO11 & Mean Temperature of Coldest Quarter & 18.0 & 12.2 \\
\hline $\mathrm{BIO} 12$ & Annual Precipitation & 644.5 & 265.9 \\
\hline $\mathrm{BIO} 13$ & Precipitation of Wettest Month; & 126.6 & 48.2 \\
\hline $\mathrm{BIO} 14$ & Precipitation of Driest Month & 6.8 & 4.0 \\
\hline $\mathrm{BIO} 15$ & Precipitation Seasonality (Coefficient of Variation) & 81.1 & 66.1 \\
\hline $\mathrm{BIO} 16$ & Precipitation of Wettest Quarter & 351.0 & 129.4 \\
\hline $\mathrm{BIO} 17$ & Precipitation of Driest Quarter & 26.9 & 19.1 \\
\hline $\mathrm{BIO} 18$ & Precipitation of Warmest Quarter & 347.0 & 22.2 \\
\hline $\mathrm{BIO} 19$ & Precipitation of Coldest Quarter & 27.8 & 128.2 \\
\hline
\end{tabular}


Lens et al. 2011). Physiological evidence for transpiration rates and hydraulic conductivity of wood in two species is required, however, to confirm or reject this explanation.

The available information on the bark structure in Picrodendraceae and its related families (Phyllanthaceae, Euphorbiaceae, Peraceae etc) is insufficient to recognize any taxonomic or evolutionary patterns in its diversity. Both A. jobnsonii and $H$. globosa show subepidermal initiation of phellogen, the presence of thick-walled fibers and sclereids as well as of axial parenchyma strands with prismatic crystals in secondary phloem. The sieve tube members in these species are also much shorter than the vessel elements that indicates the common occurrence of transverse anticlinal divisions in the differentiation of the phloem conductive elements (their secondary separation sensu Zahur (1959)). These features have also been reported in most genera of Phyllanthaceae and Euphorbiaceae examined by bark anatomists to date (Moeller 1882, Pax 1884, Zahur 1959, Roth 1981, 2005, Farías et al. 2009). At the same time, the bark of $A$. jobnsonii and $H$. globosa seemingly lacks any secretory structures which are characteristic for many members of these plant families.

Piranbea longepedunculata Jabl., the only species of Picrodendraceae whose bark structure has been explored to date (Roth 1981, 2005), differs from A. johnsonii and H. globosa in having phelloderm cells with sclerified walls, tanniniferous ("secretory") cells in secondary phloem, the presence of two types of axial parenchyma (with the strands of vertically elongated cells containing few starch grains, and those made of nearly isodiametric cells filled with starch), and also the lack of secondary phloem fibers and crystaliferous axial patenchyma. The co-occurrence of two latter traits in the species under study coupled with their loss in P. longepedunculata confirm Roth's (1981) suggestion about close association in formation of phloem fibers and crystaliferous strands of axial parenchyma.

The bark of $A$. johnsonii is conspicuous in the presence of abundant sclereids and secondary phloem fibers arranged into extended clusters or in continuous bands, and in the lack of ray dilatation. Unlike that, $H$. globosa shows only small clusters of sclereids and fibers coupled with prominent ray dilatation. Obviously, these features are associated with different ways of bark dilatation in two species. In H. globo$s a$, the expansion of bark in girth is achieved by tangential stretching and anticlinal divisions of cells in radial, axial and cortical parenchyma. As a result, a vast pseudocortex as a parenchymatous zone of mixed origin (derived from cortex and secondary phloem) is formed in outer region of its bark. Contrastingly, the presence of continuous bands of sclereids and fibers in secondary phloem of $A$. jobnsonii is hardly compatible with ray dilatation. Instead, the formation of very thick walls in those sclerenchyma cells is thought to make substantial contribution in bark expansion in this species. Similar way of bark dilatation has been reported by Mashimbye et al. (2020) in Searsia (Anacardiaceae). The continuous bands of sclereids and fibers can also perform an additional protection for the conducting secondary phloem that can be suffered otherwise by fissuring of bark due to its dilatation. The protective role of sclerified secondary phloem has been shown, for instance, in the bark of Buddleja, a genus of Scrophulariaceae (Frankiewicz et al. 2021).

Androstachys johnsonii differs from $H$. globosa also in having abundant long trichomes on epidermis of young shoots. Those are very similar to two-celled trichomes from the dense indumentum on abaxial side of the leaves of this species (Alvin 1987). Unlike A. johnsonii, H. globosa has glabrous leaves (Hayden 1994) and juvenile stems (Fig. 5A, B). Alvin (1987) suggested that the trichomes on leaves of A. johnsonii are involved in the water uptake from the aerial environment, particularly during the dry season when the water is available mostly from drizzle or mists. This function of indumentum on the juvenile stems of this species can be explained in the same way.

\section{ACKNOWLEDGEMENTS}

This work is based on the research supported by the University of Johannesburg, the Russian Foundation for Basic Research (grant no. 19-04-00714 for A.O.) and the Komarov Botanical Institute (institutional research Project No. AAAA-A19-119030190018-1 for A.O.). The authors acknowledge the CapeNature for the collecting permit.

\section{I T ERAT URE CITE D}

Alvin, K.L. 1987. Leaf anatomy of Androstachys jobnsonii Prain and its functional significance. Annals of Botany 59(5):579-591.

APG 2003. An update of the Angiosperm Phylogeny Group classification for the orders and families of flowering plants: APG II. Botanical Journal of the Linnean Society 141:399-436.

Angyalossy, V., M.R. Pace, R.F. Evert, C.R. Marcati, A.A. Oskolski, T. Terrazas, E. Kotina, F. Lens, S.C. Mazzoni-Viveiros, G. Angeles, S.R. Machado, A. Crivellaro, K.S. Rao, L. Junikka, N. Nikolaeva \& P. Baas 2016. IAWA List of microscopic bark features. LAW A Journal 37(4):517-615.

Bakali, M., M.H. Ligavha-Mbelengwa, M.J. Potgieter \& M.P. Tshisikhawe 2017. Impact of ethnobotanical utilization on the population structure of Androstachys jobnsonii Prain. in the Vhembe area of the Limpopo Province, South Africa. Insights of Forest Research 1(1):50-56.

Braun, H.J. 1970. Funktionelle Histologie der Sekundären Sprossachse I. Das Holz. Encyclopedia of plant anatomy, vol. 10, part 1. Borntraeger Gebrüder, Berlin.

Braun, H.J. 1984. The significance of the accessory tissues of the hydrosystem for osmotic water shifting as the second principle of water ascent, with some thoughts concerning the evolution of trees. LAWA Bulletin, new series 5:275-294.

Carlquist, S. 1984. Vessel grouping in dicotyledon wood: significance and relationship to imperforate tracheary elements. Aliso 10:505-525.

Carlquist, S. 2001. Comparative wood anatomy. Systematic, ecological, and evolutionary aspects of dicotyledon wood (2nd ed.), Springer-Verlag, Berlin.

Chase, M.W., D.E. Soltis, R.G. Olmstead, D. Morgan, D.H. Les, B.D. Mishler, M.R. Duvall, R.A. Price, H.G. Hills, Y.L. Qiu, K.A. Kron, J.H. Rettig, E. Conti, J.D. Palmer, J.R. Manhart, K.J. Sytsma, H.J. Michaels, W.J. Kress, K.G. Karol, W.D. Clark, M. Hedrén, B. Gaut, R.K. Jansen, K.J. Kim, C.F. Wimpee, J.F. Smith, G.R. Furnier, S.H. Strauss, Q.Y. Xiang, G.M. Plunkett, P.S. Soltis, S.M. Swensen, S.E. Williams, P.A. Gadek, C.J. Quinn, L.E. Eguiarte, E. Golenberg, G.H. Learn Jr, S.W. Graham, S.C.H. Barrett, S. Dayanandan \& V.A. Albert 1993. Phylogenetics of seed 
plants: an analysis of nucleotide sequences from the plastid gene rbcL. Annals of the Missouri Botanical Garden 80:528-580.

Chase, M.W., S. Zmarzty, M.D. Lledó, K.J. Wurdack, S.M. Swensen \& M.F. Fay 2002. When in doubt, put it in Flacourtiaceae. A molecular phylogenetic analysis based on plastid rbcL DNA sequences. Kew Bulletin 57:141-181.

Coates, P. M. 2005. Keith Coates Palgrave trees of southern Africa (3rd ed.), Struik Publishers, Cape Town.

Dyer, S., B. James \& D. James 2016. Guide to the properties and uses of Southern African wood. Briza, Pretoria.

Farías, F.R., J.S. Williamson, S.V. Rodríguez, G. Angeles \& V.O. Portugal 2009. Bark anatomy in Croton draco var. draco (Euphorbiaceae). American Journal of Botany 96(12):1-13.

Feder, N., T.P. O’Brien 1968. Plant microtechnique: some principles and new methods. American Journal of Botany 55:123-142.

Frankiewicz, K.E., J.H. Chau \& A.A Oskolski 2021. Wood and bark of Buddleja: uniseriate phellem, and systematic and ecological patterns. LAWA Journal 42(1):3-30.

Hayden, W.J. 1994. Systematic anatomy of Euphorbiaceae subfamily Oldfieldioideae I. Overview. Annals of the Missouri Botanical Garden 81( 2):180-202.

Hijmans, R.J., S.E. Cameron, J.L. Parra, P.G. Jones \& A. Jarvis 2005. Very high-resolution interpolated climate surfaces for global land areas. International Journal of Climatology 25:1965-1978.

IAWA Committee 1989. IAWA list of microscopic features for hardwood identification. IAWA Bulletin, new series 10: 219-332.

InsideWood 2004-onwards. The InsideWood Database. Published on the Internet. http://insidewood.lib.ncsu.edu/. Last accessed 04.09.2021.

Johansen, D.A. 1940. Plant Microtechnique. McGraw-Hill, New York.

Kromhout, C.P. 1975. 'n Sleutel vir die mikroskopiese uitkenning van die vernaamste inheemse houtsoorte van SuidAfrika. South African Department of Forestry Bulletin 50:124.

Lens, F., J.S. Sperry, M.A. Christman, B. Choat, D. Rabaey \& S. Jansen 2011. Testing hypotheses that link wood anatomy to cavitation resistance and hydraulic conductivity in the genus Acer. New Phytologist 190:709-723.

Maddison, W.P. \& D.R. Maddison 2019. Mesquite: a modular system for evolutionary analysis. Version 3.61. Available to http://www.mesquiteproject.org

Mashimbye, N.N., A.N. Moteetee \& A.A. Oskolski 2020. Stem and leaf structure of Searsia erosa (Thunb.) Moffett (Anacardiaceae) with systematic, ecological and ethnobotanical implications. Botanica Pacifica 9(2):103-112.

Moeller, J. 1882. Anatomie der Baumrinden. Vergleichende Studien. Springer-Verlag, Berlin, Heidelberg.

Momtaz, S., N. Lall, A. Hussein, S.N. Ostad \& M. Abdollahi 2010. Investigation of the possible biological activities of a poisonous South African plant Hyaenanche globosa (Euphorbiaceae). Pharmacognosy Magazine 6(21):34-41.

Morris, H., L. Plavcová, M. Gorai, M.M. Klepsch, M. Kotowska, H.J. Schenk, \& S. Jansen 2018. Vessel-associated cells in angiosperm xylem: Highly specialized living cells at the symplast-apoplast boundary. American Journal of Botany 105(2):151-160.
Pax, F. 1884. Die Anatomie der Euphoribiaceen in ihrer Beziehung zum System derselben. Botanische Jabrbücher 5:384 421.

Peel, M.C., B.L. Finlayson \& T.A. McMahon 2007. Updated world map of the Köppen-Geiger climate classification. Hydrology and Earth System Sciences 11:1633-1644.

Radcliffe-Smith, A. 1990. Notes on Madagascan Euphorbiaceae III: Stachyandra. Kew Bulletin 45(3):561-568.

Roth, I. 1981. Structural patterns of tropical barks. Borntraeger Gebrüder, Berlin.

Roth, I. 2005. Estructura anatómica de la corteza de algunas especies arbóreas Venezolanas de Euphorbiaceae. Acta Botánica Venezuélica 28(2):461-502.

Sano, Y., H. Morris, H. Shimada, L.P. Ronse De Craene \& S. Jansen 2011. Anatomical features associated with water transport in imperforate tracheary elements of vesselbearing angiosperms. Annals of Botany 107:953-964.

Savolainen, V., M.W. Chase, S.B. Hoot, C.M. Morton, D.E. Soltis, C. Bayer, M.F. Fay, A.Y. Bruijn, S. de, Sullivan \& Y.L. Qiu 2000. Phylogenetics of flowering plants based on combined analysis of plastid atpB and $r b c \mathrm{~L}$ gene sequences. Systematic Biology 49:306-362.

Sokoloff, D.D., M.V. Remizowa, R.M. Bateman \& P.J Rudall 2018. Was the ancestral angiosperm flower whorled throughout? American Journal of Botany 105(1):5-15.

Soltis, D.E., P.S. Soltis, D.L. Nickrent, L.A. Johnson, W.J. Hahn, S.B. Hoot, J.A. Sweere, R.K. Kuzoff, K.A. Kron, M.W. Chase, S.M. Swensen, E.A. Zimmer, S.M. Chaw, L.J. Gillespie, W.J. Kress \& K.J. Sytsma 1997. Angiosperm phylogeny inferred from $18 \mathrm{~S}$ ribosomal DNA sequences. Annals of the Missouri Bototanical Gardern 84:1-49.

Soltis, D.E., P.S. Soltis, M.W. Chase, M.E. Mort, D.C. Albach, M. Zanis, V. Savolainen, W.H. Hahn, S.B. Hoot, M.F. Fay, M. Axtell, S.M. Swensen, L.M. Prince, W.J. Kress, K.C. Nixon \& J.S. Farris 2000. Angiosperm phylogeny inferred from $18 \mathrm{~S} \mathrm{rDNA}, \mathrm{rbc} \mathrm{L}$, and atpB sequences. Botanical Journal of the Linnean Society 133: 381-461.

Van Jaarsveld, E. 2011. Hyanenanche globosa. In: PlantZAfrica, Facilitated by SANBI, South Africa. http://pza.sanbi. org/hyaenanche-globosa, accessed 07 September 2021

WCSP 2018. World Checklist of Selected Plant Families. Facilitated by the Royal Botanic Gardens, Kew. http://wcsp. science.kew.org/. Last accessed 09 September 2021.

Webster, G.L. 2014. Euphorbiaceae. In: The families and genera of vascular plants, vol. 11 (K. Kubitzki, ed.), pp. 51-216, Springer, Heidelberg, Germany.

White, J.D.M. \& J.J. Midgley 2021. Seed dispersal directed deterrence and germination in gifboom (Hyaenanche globosa; Picrodendraceae) seeds. South African Journal of Botany 137:434-439.

Whitmore, T.C. 1962a. Studies in systematic bark morphology. I. Bark morphology in Dipterocarpacae. New Phytologist 61(2):191-207.

Whitmore, T.C. 1962b. Studies in systematic bark morphology: II. General features of bark construction in Dipterocarpaceae. New Phytologist 61(2):208-220.

Zahur, M.S. 1959. Comparative study of secondary phloem of 423 species of woody dicotyledons belonging to 85 families. Memoirs Cornell University Agricultural Experiment Station 358:1-160. 